photographs of the nitration of cellulose with gaseous nitrogen pentoxide, and so to follow the process step by step. The regularity of the original cellulose structure first disappears in the direction of the fibre-axis, until a stage is reached where there remain only equatorial reflections and the pseudoperiod corresponding to the length of a glucose residue. The molecular chains then move farther apart and slide over one another so as to leave the effective residue thickness unaltered, whereupon the (101) reflection of nitro-cellulose appears. After this, little by little, the chains take up their final stable configuration and the characteristic fibreperiod $(25 \cdot 1 \mathrm{~A}$.) of trinitro-cellulose can be observed.

The whole experiment takes only an hour, and illustrates most strikingly the immediate advantages to be derived from the use of powerful $\mathrm{X}$-ray tubes. Indeed, such tubes are rapidly becoming an absolute necessity. The study of unstable systems and of physical and chemical transformations, particularly those associated with life processes, still offers an enormous field to the structure analyst. We need X-ray cinematograph films of all these things.

W. T. A.

\title{
Food Investigation: a Retrospect and the Future
}

$\mathrm{T}$ HE reconstitution of the Food Investigation Board in the autumn of 1934 provided an occasion for a review of the work accomplished by the Board during the seventeen years of its existence and the determination of the lines along which further progress should be sought.* Not only have general solutions been found, in the gasstorage of fruit and chilled meat and in the brinefreezing of fish, for the three main problems with which the Board was faced when originally established, but at the same time great advances have also been made in the science that underlies the storage and handling of foodstuffs.

Although each animal product presents its own problems of handling and storage, yet, in the final analysis, these problems may be stated more generally as those of the properties and behaviour of proteins and fats, of pigments and micro-organisms. Thus, among the main subjects of investigation have been rigor mortis and glycogenolysis in muscle; the identity and physical chemistry of animal proteins ; the freezing of colloidal systems and tissues ; the chemistry of the pigments ; the constitution of the animal fats ; and the identification and characterization of the micro-organisms found on animal products. The Board now considers that it would be profitable to take up other lines of work as opportunity offers, the most important being the organic chemistry of the proteins. It is now known, for example, that the protein myosin controls the changes taking place in meat and fish during rigor mortis, as well as the structural changes that occur during storage : in the egg, the protein mucin is the important factor. Progress has been made in determining the general physico-chemical properties of the proteins, but further advances will depend upon

* Department of Scientific and Industrial Research. Report of the Food Investigation Board for the Year 1935. Pp. $x+232$. (London: H.M. Stationery Office, 1936.) 38. 6d. net. an exact knowledge of the constituent amino acids and of their arrangement within the molecule. The results of such investigations will be of wide interest in chemistry, physiology and nutrition. The Board has therefore arranged for a member of the director's staff to spend a year in Prof. A. C. Chibnall's laboratory at the Imperial College of Science and Technology in order to gain experience of the specialized technique required, before under. taking research on this subject. It is also hoped to commence work on the identification of the autolytic enzymes of meat and eggs and the lipolytic enzymes of bacteria, to the action of which is often due the development of taint in animal foodstuffs. Although attention has hitherto been devoted chiefly to meat, the programme of research has now been widened to include both eggs and poultry, and the problems of their wastage and quality.

The handling and storage of fresh fruit present problems different in character from those of animal produce, since the material is living and not dead, and because the plants concerned belong to different orders and genera, and the parts used as foodstuffs comprise nearly all their chief organs. In spite of the work which has been carried out on the preservation of fruit and vegetables, the qualities after such periods of storage as are customary in commerce are, in general, inferior to those of the material at its best. The extension of control depends upon the advancement of our knowledge of the physico-chemical mechanism upon which the living processes are based. Up to the present, the Board has concentrated upon an intensive study of the respiration and metabolism of carbohydrate in the apple and potato. It is now including a study of the enzymes and the metabolism of nitrogen, and intends to investigate the metabolism of acid, the formation and 
breakdown of the cell wall and the nature and origin of the substances responsible for the development of colour, flavour and odour.

The Board points out the necessity of a close contact with commercial practice and describes the different steps taken to ensure the application of laboratory results in the trades concerned: thus a small laboratory is being established, in the vicinity of Smithfield Market, London, on the lines of the Covent Garden Laboratory (which is also being extended), to act as a centre for liaison with the trade. Similarly, arrangements have been made with Messrs. Crosse and Blackwell, Ltd., for the trial at Peterhead of a kiln for the smoking of fish, which is designed in accordance with the principles established at the Torry Research Station. The Board also co-operates with similar bodies in the Dominions and is stimulating research in other parts of the Empire, since it is usually essential that the problems of storage should be studied as soon as the produce has been prepared for the market, and this is not possible in Great Britain in the case of such important fruits as the orange and banana.

The report of the Board refers as usual to the changes which have taken place in its composition during the year: Prof. C. H. Lees and Sir Thomas Middleton have been appointed additional members. The Engineering Committee has been reconstituted with the following membership: Prof. C. H. Lees (chairman), Prof. E. H. Lamb, Prof. G. I. Taylor and Prof. H. E. Watson. The bulk of the report is devoted to the report of the Director of Food Investigation, Mr. E. Barnard, and is divided into sections dealing with meat, poultry and eggs, pork bacon and hams, fish, fruit and vegetables, canning and engineering. The researches at present in progress are described. by the investigators who are carrying them out.
One or two may be referred to here, to indicate some of the problems involved and the results obtained.

Two effects of the treatment of the pig immediately before slaughter on the quality of the carcass have been measured. First, fasting has been shown to increase the thickness of the flank. Secondly, the muscle of pigs overheated before slaughter has a higher electrical resistance than that of rested pigs; low resistance facilitates the penetration of salt during dry salting. Farm. killed pigs were found to have a low resistance as compared with factory-killed, and this difference was traced to the shaking which the carcasses undergo during transport to the factory.

Trials of the refrigerated gas-storage of Conference pears have been made with good results: flavour, texture and appearance are retained after long periods of storage. If soft fruits are given a preliminary heating, there is little loss of the power to set, during storage in the frozen state at $-7^{\circ} \mathrm{C}$., a temperature which inhibits the growth of moulds, or during storage with sulphurous acid. Without the preliminary heating, the power to set in jammaking is more or less rapidly lost. Apples and plums, however, do not suffer this loss under the same conditions. It has been shown that the amount of ethylene evolved by ripe apples and bananas is sufficient to initiate the ripening of green, unripe bananas. The passage of air containing one part per million of ethylene over the green fruit also causes it to begin ripening after 24 hours, but with fruit that has just started to ripen the mixture has little effect. These experiments suggest that the efficiency of ripening rooms for bananas heated with coal gas burners may be due to a slight leakage of the gas supply permitting a low concentration of ethylene in the air surrounding the fruit.

\title{
The Upper Palæolithic in the Light of Recent Discovery*
}

\author{
By Miss D. A. E. Garrod
}

$\mathrm{T}$ $\mathrm{HE}$ last twelve years have seen a new impetus given to prehistoric studies by the multiplication of researches outside Europe. Excavations in Africa, the Near East, Asiatic Russia and China have opened up a new field for speculation, and at the same time have revealed the unsuspected complexity of many problems which to De Mortillet and other pioneers seemed relatively simple. Gone for ever is the straightforward succession of

* From the presidential address to Section H (Anthropology) of the British Association, delivered at Blackpool on September 10.
Palæolithic cultures from Chellian to Magdalenian as laid down in the Musée Préhistorique. Even so early as 1912, when Breuil produced his classic paper on the subdivisions of the Upper Palæolithic, its foundations were sapped, and the discoveries of the last decade have merely completed its demolition as a system of world-wide application.

In the old system the Palæolithic cultures appeared as a straightforward succession with clearcut horizontal divisions, as in a diagrammatic geological section. The main outline of a new 